\title{
Korelasi Motivasi Belajar dengan Hasil Belajar pada Mata Kuliah TP. Pembelajaran Futsal pada Masa Pandemi Covid-19
}

\author{
Kadek Arya Sumantra $^{1 *}$, I Putu Panca Adi², I Gede Suwiwa ${ }^{3}$
}

1,2,3 Prodi Pendidikan Olahraga, Universitas Pendidikan Ganesha, Singaraja, Indonesia

\section{A R T I C L E I N F O \\ Article history: \\ Received May 24, 2021 \\ Revised May 26, 2021 \\ Accepted September 18, 2021 \\ Available online October 25, 2021}

Kata Kunci:

Covid-19, Motivasi Belajar, Hasil Belajar

\section{Keywords:}

Covid-19, Learning Motivation, Learning Outcomes

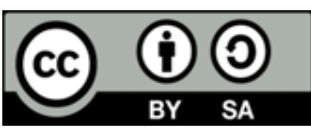

This is an open access article under the CC BY-SA license.

Copyright () 2021 by Author. Published by Universitas Pendidikan Ganesha.

\begin{abstract}
A B S T R A K
Pandemi Covid-19 telah memicu perubahan signifikan dalam sistem pendidikan di seluruh dunia yang mengakibatkan penutupan sekolah sehingga sistem pengajaran harus beralih dari pelajaran tatap muka menjadi model yang sepenuhnya virtual. Hal ini mnegakibatkan motivasi belajar peserta didik menjadi sehingga berdampak terhadap hasil belajarnya. Penelitian ini bertujuan untuk mengetahui korelasi motivasi belajar dengan hasil belajar kognitif, psikomotor, dan afektif pada mata kuliah teori praktek pembelajaran futsal pada masa pandemi covid-19. Jenis penelitian ini adalah korelasional karena penelitian ini mencari ada tidaknya hubungan antara satu variabel dengan variabel yang lain. Populasi pada penelitian ini adalah mahasiswa semester empat jurusan Penjaskes yang berjumlah 53 mahasiswa. Data yang dikumpulkan dalam penelitian ini berupa motivasi belajar dan hasil belajar kognitif, psikomtor, dan afektif. Menggunakan metode pengumpulan data berupa penyebaran kuisioner, kajian dokumentasi dan observasi. Analisis data dilakukan dengan statistik deskriptif dan uji pearson correlation. Hasil penelitian menunjukkan bahwa, terdapat korelasi motivasi belajar dengan hasil belajar kognitif, psikomotor, dan afektif pada mata kuliah teori praktek pembelajaran futsal pada masa pandemi covid-19 mahasiswa jurusan pendidikan jasmani dan kesehatan universitas pendidikan ganesha singaraja.
\end{abstract}

\section{A B S T R A K}

The Covid-19 pandemic has triggered significant changes in education systems around the world, resulting in school closures requiring the teaching system to shift from face-to-face lessons to a completely virtual model. It causes students' learning motivation to become so that it impacts their learning outcomes. This study aims to determine the correlation of learning motivation with cognitive, psychomotor, and affective learning outcomes in the practical theory course of futsal learning during the covid-19 pandemic. This type of research is correlational because this research seeks whether there is a relationship between one variable and another. The population in this study was the fourthsemester students majoring in Physical Education, amounting to 53 students. The data collected in this study were learning motivation and cognitive, psychomotor, and affective learning outcomes and using data collection methods to distribute questionnaires, reviewing documentation and observations. Data analysis was performed using descriptive statistics and the Pearson correlation test. The results showed a correlation between learning motivation and cognitive, psychomotor, and affective learning outcomes in the practical theory course of futsal learning during the COVID-19 pandemic for students majoring in physical education and health at the Ganesha Singaraja University of Education.

\section{PENDAHULUAN}

Pada saat ini sistem pendidikan di dunia terganggu oleh adanya wabah Covid-19. Covid-19 merupakan penyakit yang diidentifikasikan penyebabnya adalah virus Corona yang menyerang saluran pernapasan (Putri \& Purwanto, 2020; Susilo et al., 2020). Penyakit ini pertama kali dideteksi kemunculannya di Wuhan, Tiongkok (Lee \& Hsueh, 2020; Zhu et al., 2020). Wabah penyakit Coronavirus (COVID-19) yang penyebarannya di China tersebut menjadi perhatian utama dunia kesehatan dan menyebabkan kepanikan serta kekhawatiran publik yang besar. Organisasi Kesehatan Dunia (WHO) 
menyatakan bahwa wabah virus corona sebagai keadaan darurat kesehatan masyarakat yang menjadi perhatian dunia internasional serta mengumumkan bahwa status covid-19 sebagai pandemi dan mengharuskan seluruh dunia segera melakukan upaya menghentikan dan mengatasi dampak yang ditimbulkannya.

Wabah virus corona mulai masuk ke Indonesia pada awal maret tahun 2020. Berdasarkan hal tersebut maka pemerintah Indonesia berupaya menekan penyebarannya dengan melakukan pembatasan fisik atau physical distancing (Anugrahana, 2020; Ardan, Rahman, \& Geroda, 2020; Buana, 2020). Sebagai akibat dari pembatasan menimbulkan banyak perubahan berbagai aspek kehidupan sosial, ekonomi, budaya, bahkan pendidikan (Ismawati \& Prasetyo, 2021; Sadikin, A., \& Hamidah, 2020). Pada aspek pendidikan kebijakan yang di ambil pemerintah adalah pembelajaran secara daring (Kusmaharti \& Yustitia, 2020; Rahmawati \& Nazarullail, 2020). Berdasarkan kebijakan tersebut maka sistem pembelajaran di kampus berubah secara drastis dari pertemuan tatap muka menjadi pembelajaran secara online. Agar proses pendidikan tidak berhenti begitu saja akibat virus corona, sesuai kebijakan yang dibuat oleh pemerintah, mahasiswa diminta untuk belajar dari rumah dan tetap melaksanakan tugasnya sebagai peserta didik dengan mengikuti proses pembelajaran melalui media online via WhatsApp, Zoom Meeting, Google Meet, dan berbagai virtual account lainnya (Dhull, 2017; Pratiwi, 2020; Sukawati, 2021). Pembelajaran daring membantu menyediakan akses belajar bagi semua orang, sehingga hambatan secara fisik sebagai faktor untuk belajar dapat diatasi (Riaz, 2018). Pembelajaran daring adalah suatu yang baru yang dianggap efektif untuk diterapkan khususnya dalam perguruan tinggi, namun tidak bisa dipungkiri bahwa tidak semua pembelajaran dapat dipindahkan ke dalam lingkungan pembelajaran secara online (Pilkington, 2018). Pembelajaran daring memungkinkan mahasiswa memiliki keleluasaan waktu belajar sehingga dapat belajar kapanpun dan dimanapun. Dengan pembelajaran daring diharpakan mahasiswa mampu mengikuti proses perkuliahan dengan baik dan memperoleh hasil yang baik.

Namun kenyataannya pada pelaksanaan pembelajaran melalui media online banyak kendala yang dirasakan oleh mahasiswa. Hal ini sejalan dengan hasil observasi observasi dan wawancara terhadap beberapa mahasiswa di Universitas Pendidikan Ganesha Singaraja pada Fakultas Olahraga dan Kesehatan menunjukan bahwa dalam kondisi pandemi COVID-19 proses pembelajaran tetap berjalan seperti biasanya. Pembelajaran melalui media online dapat diikuti oleh mahasiswa dengan baik meskipun ada beberapa kendala diantaranya fasilitas internet yang kurang memadai, proses pembelajaran yang kurang bisa dipahami, materi pembelajaran yang kurang menarik serta tugas yang terlalu banyak. Sehingga hal tersebut berdampak pada menurunnya motivasi belajar mahasiswa . Rendahnya motivasi belajar akan mempengaruhi hasil belajar dari proses pembelajaran (Angreini, Muhiddin, \& Nurlina, 2020; Lestari, Kristiantari, \& Ganing, 2017; Maulana Arafat Lubis, 2016; Sholekah, 2020). Hal ini menyebabkan proses pembelajarn terkesan kurang optimal (Harni, 2021; Rudi Sofyan, 2016).

Faktor-faktor yang mempengaruhi hasil belajar secara garis besar dapat dibedakan menjadi dua yaitu faktor internal dan faktor eksternal (Prasetyo \& Nabillah, 2019; Rosalina \& Junaidi, 2020). Faktor eksternal yaitu faktor yang timbul dari luar diri mahasiswa diantaranya dosen, teman, fasilitas belajar, lingkungan sekolah, sumber belajar, pendapatan orang tua dan lain-lain. Sedangkan faktor internal yaitu faktor yang timbul dari dalam diri mahasiswa itu sendiri diantaranya keadaan fisik, intelegensi, bakat, minat, motivasi, kemandirian, dan perhatian (Karina, Syafrina, \& Habibah, 2017; Slameto, 2010). Faktor intern yang mempengaruhi dalam mencapai keberhasilan proses pembelajaran mahasiswa salah satunya adalah motivasi belajar (Fitriyani \& Sari, 2020; Nirfayanti \& Nurbaeti, 2019). Motivasi dapat dikatakan serangkaian usaha untuk menyediakan kondisi-kondisi tertentu, sehingga seseorang mau dan ingin melakukan sesuatu, dan bila ia tidak suka, maka akan berusaha untuk meniadakan atau mengelakkan perasaan tidak suka itu (Ahdan, Putri, \& Sucipto, 2020; Prabawa \& Restami, 2020).

Dalam proses belajar mengajar motivasi sangat besar peranannya terhadap hasil belajar. Karena dengan adanya motivasi dapat menumbuhkan minat belajar mahasiswa. Pada semua usia, motivasi memainkan peran yang sangat penting dalam kehidupan seseorang dan mempunyai dampak yang besar. Mahasiswa yang memiliki motivasi belajar tinggi cenderung akan mempunyai sikap positif untuk berhasil (Jemudin, Makur, \& Ali, 2019; Pambudhi \& Retnowati, 2017). Lain halnya bagi mahasiswa yang tidak ada motivasi di dalam dirinya, maka akan menyebabkan hasil belajar mahasiswa menjadi rendah. Seperti kurangnya perhatian mahasiswa saat dosen menjelaskan materi di kelas dan berbicara dengan teman sebangku saat dosen menjelaskan materi, hal ini terjadi karena kurangnya motivasi belajar pada diri mahasiswa motivasi untuk mendapatkan hasil yang tinggi. Motivasi sangat berperan dalam belajar, dengan motivasi inilah mahasiswa menjadi tekun dalam proses belajar mengajar, dan dengan motivasi itu pula kualitas hasil belajar mahasiswa dapat diwujudkan dengan baik. Tingginya motivasi dalam belajar berhubungan dengan tingginya hasil belajar.

Hal ini relevan dengan hasil penelitian yang dilakukan oleh (Marlini, 2021) yang menunjukkan bahwa motivasi memberikan suatu dorongan kehendak yang menyebabkan seseorang melakukan untuk 
perbuatan untuk mencapai tujuan tertentu. Motivasi memberika pengaruh signifikan terhadap hasil belajar siswa (Suyanti, Sari, \& Rulviana, 2021). Penelitian oleh (Ricardo \& Meilani, 2017) menunjukkan bahwa peningkatan motivasi belajar siswa selama pembelajaran online menunjukkan adanya pengaruh terhadap hasil belajar siswa. Keatifan siswa dalam proses pembelajaran, terbukti dengan hasil belajar yang mengalami perubahan positif yang terlihat drai hasil belajar yang meningkat (Agustina, Azizah, \& Koesmadi, 2021).

Mengingat pentingnya motivasi belajar dalam proses pembelajaran daring, maka penelitian ini dilaksanakan. Penelitian ini berbeda dengan penelitian yang sudah ada, yang mana penelitian ini dilakukan di tingat mahasiswa dengan aspek yang diteliti adalah indikator motivasi belajar yang berdamapk terhadap hasil belajar. Penelitian ini dilakukan dengan tujuan untuk mengetahui korelasi motivasi belajar dengan hasil belajar kognitif, psikomotor, dan afektif pada mata kuliah teori praktek pembelajaran futsal pada masa pandemi covid-19. Diharpkan penelitian ini dapat dijadikan menjadi bahan evaluasi dalam menciptakan pembelajaran daring yang efektif serta motivasi mahasiswa ditengah Pandemik covid-19.

\section{METODE}

Metode penelitian yang digunakan dalam penelitian ini termasuk jenis korelasional karena penelitian ini mencari ada tidaknya hubungan antara satu variabel dengan variabel yang lain. Dilihat dari sifatnya termasuk desain penelitian asosiatif kausal yaitu untuk mengetahui hubungan motivasi belajar dengan hasil belajar. Pendekatan yang digunakan dalam penelitian ini adalah pendekatan kuantitatif karena dalam penelitian ini dituntut menggunakan angka, mulai dari pengumpulan data, penafsiran terhadap data tersebut, serta penampilan dari hasilnya. Subyek penelitian ini adalah semua mahasiswa Penjaskesrek semester empat pada bulan Mei sampai Juli 2021. Populasi dalam penelitian ini adalah mahasiswa semester empat jurusan Penjaskes yang berjumlah 53 mahasiswa. Apabila subyek penelitian berjumlah kurang dari 100, maka lebih baik diambil semua sehingga penelitiannya merupakan penelitian populasi (Arikunto, 2006:112). Menggunakan metode pengumpulan data berupa penyebaran kuisioner, kajian dokumentasi dan observasi. Instrumen penelitian dilakukan dengan melakukan tahap-tahap berupa membuat kisi-kisi, menyusun butir pertanyaan, membuat skorsing, uji coba instrument, validitas isi, konsistensi internal butir dan reliabiltas tes. Pada penelitian ini digunakan dua teknik analisis yaitu analisis statistik deskriptif dan analisis korelasi Product Moment dari Karl Person.

\section{HASIL DAN PEMBAHASAN}

Hasil

Berdasarkan hasil anakisi pembelajaran Futsal secara daring pada pandemi covid-19 berada pada kualifikasi sangat tinggi 7 orang mahasiswa $(13,21 \%), 41$ orang mahasiswa $(77,36 \%)$ kualifikasi tinggi, 5 orang mahasiswa $(9,43 \%)$ kualifikasi cukup, sedangkan kualifikasi kurang dan sangat kurang tidak ada. Untuk hasil belajar kognitif mahasiswa semester empat yang mengambil mata kuliah TP. Pembelajaran Futsal secara daring pada masa pandemi covid-19 terlihat bahwa sebanyak 16 orang mahasiswa (30,19\%) berada pada kulaifikasi sangat tinggi, dan yang terkualifiksai tinggi sebanyak 37 orang mahasiswa (69,81\%) sedangkan yang terkualifikasi cukup, kurang, dan sangat kurang tidak ada mahasiswa yang mencapainya. Kemudian untuk hasil belajar psikomotor terlihat bahwa sebanyak 21 orang mahasiswa $(39,62 \%)$ terkualifikasi sangat tinggi, 28 orang mahasiswa $(52,83 \%)$ terkualifikasi tinggi, 4 orang mahasiswa $(7,55 \%)$ terkualifikasi cukup, dan yang terkualifikasi kurang dan sangat kurang tidak ada. Sedangkan untuk hasil belajar afektif sebanyak 53 orang mahasiswa (100\%) mencapai kualifikasi sangat tinggi, dan yang terkualifikasi tinggi, cukup, kurang serta sangat kurang tidak ada.

\section{Pengujian Persyaratan Analisis}

1. Normalitas

Normalitas pada penelitian ini dilakukan untuk mengetahui apakah semua variabel penelitian berdistribusi normal atau tidak. Normalitas diujikan pada masing-masing variabel penelitian yang meliputi motivasi belajar dan hasil belajar kognitif, psikomotor dan afektif mahasiswa. Pengujian normalitas menggunakan teknik analisis Kolmogorov-Smirnov dan untuk perhitungannya menggunakan program SPSS 22.00 for Windows. Data dikatakan berdistribusi normal apabila nilai signifikansi lebih besar dari 0,05 pada taraf signifikansi $\alpha=0,05$.

\section{Liniearitas}

Uji Linearitas bertujuan untuk mengetahui apakah dua variabel mempunyai hubungan yang 
linear atau tidak secara signifikan. Uji linearitas dilakukan dengan statistik deviation from liniarity. Kriteria pengujiannya adalah data memiliki hubungan yang linear atau tidak secara signifikan jika angka signifikansi yang diperoleh lebih besar dari 0,05 dan dalam hal lain sebaran tidak terjadi hubungan yang liniaritas.

\section{Pengujian Hipotesis}

Pada penelitian ini diajukan tiga hipotesis. Ketiga pengujian hipotesis tersebut menggunakan analisis korelasi Product Moment dari Karl Person.

Tabel 1. Hipotesis Pertama

\begin{tabular}{cccc}
\hline & & MOTIVASI & HBK \\
\hline \multirow{2}{*}{ MOTIVASI } & Pearson Correlation & 1 & $0,929^{* *}$ \\
& Sig. (2-tailed) & & 0,000 \\
& $\mathrm{~N}$ & 53 & 53 \\
HBK & Pearson Correlation & $0,929^{* *}$ & 1 \\
& Sig. (2-tailed) & 0,000 & 53 \\
\hline
\end{tabular}

Pada hipotesis pertama yakni terdapat korelasi motivasi belajar dengan hasil belajar kognitif pada mata kuliah teori praktek pembelajaran futsal pada masa pandemi covid-19 mahasiswa jurusan pendidikan jasmani dan kesehatan universitas pendidikan ganesha singaraja dapat diuji menggunakan uji analisis korelasi Product Moment dari Karl Person. Dasar pengambilan keputusan menggunakan koefisien korelasi (rxy). Jika koefisien korelasi bernilai positif maka dapat dilihat adanya hubungan yang positif antara motivasi belajar dan hasil belajar kognitif. Sedangkan untuk menguji signifikansi adalah dengan membandingkan nilai sig. dengan taraf signifikansi 5\%. Jika nilai sig. $<0,05$ maka hubungan tersebut signifikan. Sebaliknya jika nilai sig.>0,05 maka hubungan tersebut tidak signifikan.

Tabel 2. Hipotesis Kedua

\begin{tabular}{cccc}
\hline & & Motivasi & HBP \\
\hline \multirow{2}{*}{ Motivasi } & Pearson Correlation & 1 & $0,681^{* *}$ \\
& Sig. (2-tailed) & & 0,000 \\
& $\mathrm{~N}$ & 53 & 53 \\
HBP & Pearson Correlation & $0,681^{* *}$ & 1 \\
& Sig. (2-tailed) & 0,000 & 53 \\
\hline
\end{tabular}

Pada hipotesis kedua yakni terdapat korelasi motivasi belajar dengan hasil belajar psikomotor pada mata kuliah TP. Pembelajaran Futsal pada masa pandemi covid-19 mahasiswa jurusan Pendidikan Olahraga Universitas Pendidikan Ganesha Singaraja dapat diuji menggunakan uji analisis korelasi Product Moment dari Karl Person. Dasar pengambilan keputusan menggunakan koefisien korelasi (rxy). Jika koefisien korelasi bernilai positif maka dapat dilihat adanya hubungan yang positif antara motivasi belajar dan hasil belajar psikomotor. Sedangkan untuk menguji signifikansi adalah dengan membandingkan nilai sig. dengan taraf signifikansi 5\%. Jika nilai sig. < 0,05 maka hubungan tersebut signifikan. Sebaliknya jika nilai sig. $>0,05$ maka hubungan tersebut tidak signifikan.

Tabel 3. Hipotesis Ketiga

\begin{tabular}{cccc}
\hline & & Motivasi & HBA \\
\hline \multirow{2}{*}{ Motivasi } & Pearson Correlation & 1 & $0,420^{* *}$ \\
& Sig. (2-tailed) & & 0,002 \\
& $\mathrm{~N}$ & 53 & 53 \\
HBA & Pearson Correlation & $0,420^{* *}$ & 1 \\
& Sig. (2-tailed) & 0,002 & 53 \\
\hline
\end{tabular}

Pada hipotesis pertama yakni terdapat korelasi motivasi belajar dengan hasil belajar afektif pada mata kuliah TP. Pembelajaran Futsal pada masa pandemi covid-19 mahasiswa jurusan Pendidikan 
Olahraga Universitas Pendidikan Ganesha Singaraja dapat diuji menggunakan uji analisis korelasi Product Moment dari Karl Person. Dasar pengambilan keputusan menggunakan koefisien korelasi (rxy). Jika koefisien korelasi bernilai positif maka dapat dilihat adanya hubungan yang positif antara motivasi belajar dengan hasil belajar afektif. Sedangkan untuk menguji signifikansi adalah dengan membandingkan nilai sig. dengan taraf signifikansi 5\%. Jika nilai sig. $<0,05$ maka hubungan tersebut signifikan. Sebaliknya jika nilai sig.>0,05 maka hubungan tersebut tidak signifikan.

\section{Pembahasan}

Berdasarkan hasil analisis menunjukkan terdapat hubungan positif dan signifikan motivasi belajar dengan hasil belajar kogintif, psikomotor, dan afektif pada mata kuliah TP. Pembelajaran Futsal pada masa pandemi covid-19 mahasiswa jurusan Pendidikan Olahraga Universitas Pendidikan Ganesha Singaraja. Dalam proses belajar mengajar yang dikasanakan secara daring pada pandemi covid-19, keberhasilan dan kegagalan tidak dapat dilihat dari satu faktor saja tetapi perlu memandang dari berbagai segi atau faktor yang mempengaruhi. Salah satu faktor yang berasal dari dalam mahasiswa adalah motivasi belajar. Motivasi untuk belajar adalah kondisi psikologis yang mendorong mahasiswa untuk belajar pada pandemi covid-19. Penemuan-penemuan penelitian sebelumnya seperti yang diungkapkan di atas menunjukkan bahwa hasil belajar pada umumya meningkat jika motivasi untuk belajar bertambah. Motivasi belajar mahasiswa merupakan daya penggerak dalam diri mahasiswa untuk dapat mencapai hasil belajar mahasiswa yang optimal, sehingga tujuan yang dikehendaki subjek belajar itu dapat tercapai.

Munculnyaa motivasi dalam diri mahasiswa dipengaruhi oleh faktor internal dan eksternal. Faktor internal adalah faktor yang muncul dari dalam seperti faktor fisik maupun psikis. Motivasi eksternal ialah motivasi yang muncul luar diri seperti, keluarga, dosen, guru dan lingkungan sekitar. Perilaku dan keterampilan yang dimiliki oleh peserta didik yang berasal dari dalam diri merupakan faktor penentu keberhasilan belajar dan dapat juga dibantu oleh faktor eksternal atau dorongan dari luar yang mampu meningkatkan motivasi belajar dengan cara memperhatikan gaya belajar sehingga lebih nyaman (Fath \& Sugito, 2021). Motivasi belajar merupakan daya penggerak dalam diri mahasiswa untuk mampu mencapai hasil belajar yang optimal sehingga tujuan yang dikehendaki dalam belajar dapat tercapai. Mahasiswa yang memiliki motivasi yang tinggi dalam belajar akan mampu melaksanakan kegiatan belajar dengan tanggung jawab dan keyakinan penuh bila dibandingkan dengan mahasiswa yang memiliki motivasi belajar yang rendah, sehingga hasil belajar yang dicapai mampu didapat secara optimal (Ricardo \& Meilani, 2017; Yuliany, 2018).

Motivasi belajar yang tinggi tercemin dari ketekunan yang tidak mudah patah untuk mencapai sukses meskipun dihadang oleh berbagai kesulitan termasuk pembelajaran yang dilaksanakan secara daring pada pandemi covid-19 saat ini. Motivasi belajar menghasilkan hubungan pedagosis antara dosen dan mahasiswa yang saling timbal balik, yang mampu meningkatkan konsentrasi mahasiswa, sehingga aplikasi yang mendukung proses belajar, dan pemanfaatan media dan bahan ajar yang interaktif mampu di gunakan dengan maksimal (Fitriyani \& Sari, 2020; Permana, 2016). Motivasi yang tinggi dapat menggiatkan aktivitas belajar serta membangun rasa ingin tahu mahasiswa (Fauzi, A. R. \& Atok, 2017). Dengan demikian dapat disimpulkan bahwa mahasiswa yang memiliki motivasi belajar tinggi mempunyai peluang lebih besar untuk memperoleh prestasi belajar yang lebih baik dibandingkan mahasiswa yang memiliki motivasi belajar rendah.

Hasil penelitian ini sejalan dengan penelitian yang dilakukan oleh (Budiariawan, 2019; Pratama, Firman, \& Neviyarni, 2019) yang menyatakan bahwa ada korelasi positif antara motivasi belajar dengan hasil belajar siswa. Penelitian yang dilakukan oleh (Dharma \& Sudewiputri, 2021) yang menunjukkan bahwa ditengah pandemic covid 19 motivasi mahasiswa belajar menunjukkan kriteria baik. Penelitian oleh (Ayatollah, 2018; Palittin, Wolo, \& Purwanty, 2019) menunjukkan bahwa motivasi belajar yang tinggi akan berpengaruh terhadap meningkatnya hasil belajar secara signifikan. Berdasarkan analisis hasil penelitian yang didukung oleh beberapa penelitian terdahulu dapat dikatakan bahwa motivasi belajar berpengaruh terhadap hasil belajar mahasiswa. Sehingga penting untuk dosen mampu menciptakan suasana pembelajarn yang efektif sehingga mahasiswa mamiliki rasa ingin tahu dan tanggung jawab dala mengikuti kegiatan pembelajaran ditengah pandemic covid-19.

\section{SIMPULAN DAN SARAN}

Berdasarkan hasil penelitian dan kesimpulan yang telah diuraikan di atas, diketahui motivasi belajar berkorelasi terhadap hasil belajar kognitif, psikomotor, dan afektif, oleh karena itu, dosen pengajar mata kuliah TP. Pembelajaran Futsal harus selalu memberikan dorongan agar motivasi belajar para mahasiswa meningkat dengan cara menggunakan metode belajar yang baru dan menarik serta menciptakan lingkungan belajar yang nyaman sehingga mampu meningkatkan konsentrasi mahasiswa 
dalam proses pembelajaran daring pada pandemi covid-19 sehingga dapat meningkatkan hasil belajar mahasiswa itu sendiri.

\section{DAFTAR RUJUKAN}

Agustina, M., Azizah, E. N., \& Koesmadi, D. P. (2021). Pengaruh Pemberian Reward Animasi terhadap Motivasi Belajar Anak Usia Dini selama Pembelajaran Daring. Jurnal Obsesi : Jurnal Pendidikan Anak Usia Dini, 6(1), 353-361. https://doi.org/10.31004/obsesi.v6i1.1331.

Ahdan, S., Putri, A. R., \& Sucipto, A. (2020). Aplikasi M-Learning Sebagai Media Pembelajaran Conversation Pada Homey English. Sistemasi, 9(3), 493. https://doi.org/10.32520/stmsi.v9i3.884.

Angreini, D., Muhiddin, M., \& Nurlina, N. (2020). Pengaruh Penggunaan Media Audio Visual Terhadap Motivasi dan Hasil Belajar IPA Siswa Kelas V SD Negeri Bontoramba. Edumaspul: Jurnal Pendidikan, 4(1). https://doi.org/https://doi.org/10.33487/edumaspul.v4i1.199.

Anugrahana, A. (2020). Hambatan, Solusi dan Harapan: Pembelajaran Daring Selama Masa Pandemi Covid-19 Oleh Guru Sekolah Dasar. Scholaria: Jurnal Pendidikan Dan Kebudayaan, 10(3), 282-289. https://doi.org/10.24246/j.js.2020.v10.i3.p282-289.

Ardan, M., Rahman, F. F., \& Geroda, G. B. (2020). The influence of physical distance to student anxiety on COVID-19, Indonesia. Journal of Critical Reviews, 7(17), 1126-1132. https://doi.org/10.31838/jcr.07.17.141.

Ayatollah. (2018). Upaya Meningkatkan Motivasi dan Hasil Belajar Siswa Pada Mata Pelajaran Pendidkan Agama Islam Menggunakan Metode Demonstrasi Dan Media Nyata Pada Kelas IV SDN 3 Sepit Tahun Pelajaran 2017/2018. FONDATIA: Jurnal Pendidikan Dasar, 2(2), 61-82. https://doi.org/10.36088/fondatia.v2i2.127.

Buana, D. R. (2020). Analisis Perilaku Masyarakat Indonesia dalam Menghadapi Pandemi Virus Corona (Covid-19) dan Kiat Menjaga Kesejahteraan Jiwa. Salam: Jurnal Sosial Dan Budaya Syar-I, 217226. http://journal.uinjkt.ac.id/index.php/salam/article/view/15082/0.

Budiariawan, I. P. (2019). Hubungan Motivasi Belajar Dengan Hasil Belajar Pada Mata Pelajaran Kimia. Jurnal Pendidikan KImia Indonesia, 3(2). https://doi.org/10.23887/jpk.v3i2.21242.

Dharma, I. M. A., \& Sudewiputri, M. P. (2021). Motivasi Belajar Mahasiswa pada Pembelajaran Daring Selama Pandemik Covid-19. Jurnal Pedagogi Dan Pembelajaran, 4(2), 295-301. https://doi.org/10.23887/jp2.v4i2.38899.

Dhull, I. dan S. (2017). Online Learning. International Education \& Research Journal (IERJ), 3(8), 32-34.

Fath, A. M. AL, \& Sugito. (2021). Meningkatkan Motivasi Belajar Siswa Kelas Iv Melalui Media Video. Elementary School, 8(2), 58-66. https://journal.upy.ac.id/index.php/es/article/view/1394/0.

Fauzi, A. R., Z., \& Atok, R. Al. (2017). Penguatan Karakter Rasa Ingin Tahu dan Peduli Sosial melalui Discovery Learning. Jurnal Teori Dan Praksis Pembelajaran IPS, 2(2). http://journal2.um.ac.id/index.php/jtppips/article/view/2500/0.

Fitriyani, \& Sari. (2020). Motivasi Belajar Mahasiswa Pada Pembelajaran Daring Selama Pandemik Covid19. Jurnal Kependidikan: Jurnal Hasil Penelitian Dan Kajian Kepustakaan Di Bidang Pendidikan, Pengajaran, Dan Pembelajaran, 6(2), 165-175. https://doi.org/https://doi.org/10.33394/jk.v6i2.2654.

Harni, H. (2021). Penerapan Model Pembelajaran Inkuiri untuk Meningkatkan Motivasi dan Hasil Belajar Siswa pada Materi Cahaya dan Sifat-Sifatnya di SD Negeri 2 Uebone. Jurnal Paedagogy, 8(2), 181. https://doi.org/10.33394/jp.v8i2.3481.

Ismawati, D., \& Prasetyo, I. (2021). Efektivitas Pembelajaran Menggunakan Video Zoom Cloud Meeting pada Anak Usia Dini Era Pandemi Covid-19. Jurnal Obsesi : Jurnal Pendidikan Anak Usia Dini, 5(1), 665-675. https://doi.org/10.31004/obsesi.v5i1.671.

Jemudin, F. DE, Makur, A. P., \& Ali, F. A. (2019). Hubungan Sikap Belajar Dan Motivasi Belajar Terhadap Prestasi Belajar Matematika Siswa Smpn 6 Langke Rembong. Journal of Hanoi Math, 2(1). https://doi.org/https://doi.org/10.30862/jhm.v2i1.53.

Karina, R. M., Syafrina, A., \& Habibah, S. (2017). Hubungan Antara Minat Belajar Dengan Hasil Belajar Siswa Dalam Mata Pelajaran Ipa Pada Kelas V Sd Negeri Garot Geuceu Aceh Besar. Jurnal Ilmiah Pendidikan Guru Sekolah Dasar, 2(1), 61-77. http://www.jim.unsyiah.ac.id/pgsd/article/view/4396.

Kusmaharti, D., \& Yustitia, V. (2020). Efektivitas Online Learning t erhadap Kemampuan Pemecahan Masalah Matematika Mahasiswa. Journal of Medives: Journal of Mathematics Education IKIP Veteran Semarang, 4(2), 311-318. https://doi.org/10.31331/medivesveteran. v4i2.1199.

Lee, P.-I., \& Hsueh, P.-R. (2020). Lee, P. I., \& Hsueh, P. R. (2020). Emerging Threats From Zoonotic Coronaviruses-From SARS And MERS To 2019-Ncov. Journal of Microbiology, Immunology and 
Infection., 53(3), 365-367. https://doi.org/10.1016/j.jmii.2020.02.001.

Lestari, Kristiantari, \& Ganing. (2017). Pengaruh Model Pembelajaran Talking Stick Berbantuan Lagu Daerah Terhadap Hasil Belajar IPS. International Journal of Elementary Education, 4(1). https://doi.org/http://dx.doi.org/10.23887/ijee.v1i4.12960.

Marlini, K. D. (2021). Penerapan Model Pembelajaran Problem Based Instruction (Pbi) Untuk Meningkatkan Minat Dan Prestasi Belajar Pkn Siswa Kelas X Mm-2 Smk Negeri 1 Denpasar Pada Semester Ganjil Tahun Pelajaran 2019/2020. Jurnal Pendidikan Kewarganegaraan Undiksha, 9(1), 197-204. https://doi.org/10.23887/jpku.v9i1.31956.

Maulana Arafat Lubis, M. P. (2016). Pembelajaran Tematik di SD/MI Pengembangan Kurikulum 2013. (A. C, Ed.), CEUR Workshop Proceedings (pertama, Vol. 13). Yogyakarta: Katalog Dalam Terbitan (KDT) (C).

Nirfayanti, N., \& Nurbaeti, N. (2019). Pengaruh Media Pembelajaran Google Classroom Dalam Pembelajaran Analisis Real Terhadap Motivasi Belajar Mahasiswa. Proximal Jurnal Penelitian Matematika Dan Pendidikan Matematika ISSN 26158132 (Cetak) ISSN 26157667 (Online), 2(1), 50-59. https://e-journal.my.id/proximal/article/download/211/173/.

Palittin, I. D., Wolo, W., \& Purwanty, R. (2019). Hubungan Motivasi Belajar Dengan Hasil Belajar Fisika. Magistra: Jurnal Keguruan Dan Ilmu Pendidikan, 6(2), 101-109. https://doi.org/10.35724/magistra.v6i2.1801.

Pambudhi, T., \& Retnowati, T. H. (2017). Pengembangan Modul Pembelajaran Tematik Integratif Berkarakter Nasionalisme Kelas Iv Sekolah Dasar Daerah Banyumas. Jurnal Pendidikan Karakter, 7(1), 71-85. https://doi.org/10.21831/jpk.v7i1.15502.

Permana, A. (2016). Pengaruh Gaya Belajar dan Motivasi Belajar Mahasiswa Terhadap Kemampuan Belajar Ilmu Alamiah Dasar. Formatif: Jurnal Ilmiah Pendidikan MIPA. https://doi.org/10.30998/formatif.v6i3.999.

Pilkington, O. A. (2018). Active Learning for an Online Composition Classroom: Blogging as an Enhancement of Online Curriculum. Journal of Educational Technology Systems, 47(2), 1-14. https://doi.org/https://doi.org/10.1177/0047239518788278.

Prabawa, D. G. A. P., \& Restami, M. P. (2020). Pengembangan Multimedia Tematik Berpendekatan Saintifik untuk Siswa Sekolah Dasar. Mimbar PGSD Undikhsa, 8(3), 479-491. https://ejournal.undiksha.ac.id/index.php/JJPGSD/article/view/28970.

Prasetyo, A. A., \& Nabillah, T. (2019). Faktor Penyebab Rendahnya Hasil Belajar Siswa. Sesiomadika, 2(3), 659-663. https://journal.unsika.ac.id/index.php/sesiomadika/article/view/2685/1908.

Pratama, F., Firman, \& Neviyarni. (2019). Pengaruh Motivasi Belajar IPA Siswa Terhadap Hasil Belajar Di Sekolah Dasar Negeri 01. Jurnal Ilmu Pendidikan, 1(3), 280-286. https://doi.org/https://doi.org/10.31004/edukatif.v1i3.63.

Pratiwi, E. W. (2020). Dampak Covid-19 Terhadap Kegiatan Pembelajaran Online Di Perguruan Tinggi Kristen Di Indonesia. Perspektif Ilmu Pendidikan, 34(1), 1-8. https://doi.org/10.21009/pip.341.1.

Putri, R. S., \& Purwanto, D. (2020). (2020). Impact of the COVID-19 pandemic on online home learning: An explorative study of primary schools in Indonesia. International ,. Journal of Advanced Science and Technology, 29(5), 4809-4818. http://sersc.org/journals/index.php/IJAST/article/view/13867.

Rahmawati, R. L., \& Nazarullail, F. (2020). Strategi Pembelajaran Outing Class Guna Meningkatkan Aspek Perkembangan Anak Usia Dini. Jurnal PG-PAUD Trunojoyo : Jurnal Pendidikan Dan Pembelajaran Anak Usia Dini, 7(2), 9-22. https://doi.org/10.21107/pgpaudtrunojoyo.v7i2.8839.

Riaz, A. (2018). Effects of Online Education on Encoding and Decoding Process of Students and Teachers. International Conference E-Learning, 42-48. https://doi.org/https://files.eric.ed.gov/fulltext/ED590288.pdf.

Ricardo, \& Meilani, R. I. (2017). Impak Minat dan Motivasi Belajar Terhadap Hasil Belajar Siswa. Jurnal Pendidikan Manajemen Perkantoran, 2(2), 79. https://doi.org/10.17509/jpm.v2i2.8108.

Rosalina, L., \& Junaidi, J. (2020). Hubungan Minat Belajar Dengan Hasil Belajar Pada Pembelajaran Sosiologi Pada Kelas XII IPS di SMAN 5 Padang. Jurnal Sikola: Jurnal Kajian Pendidikan Dan Pembelajaran, 1(3), 175-181. https://doi.org/10.24036/sikola.v1i3.24.

Rudi Sofyan. (2016). Pengembangan Media Pembelajaran Tematik Berbasis Multimedia Interaktif Pada Subtema Ayo Cintai Lingkungan. PEDADIDAKTIKA: Jurnal Ilmiah Pendidikan Guru Sekolah Dasar, 3(2), 272-280. https://ejournal.upi.edu/index.php/pedadidaktika/article/view/5157.

Sadikin, A., \& Hamidah, A. (2020). Pembelajaran Daring di Tengah Wabah Covid-19. Biodik, 6(2), 109-119. https://doi.org/10.22437/bio.v6i2.9759.

Sholekah, A. W. (2020). Peningkatan Motivasi Dan Hasil Belajar IPA Materi Pencemaran Lingkungan Melalui Model PjBL Siswa Kelas VII SMPN 9 Salatiga. JURNAL PENDIDIKAN MIPA, 10(1), 16-22. https://doi.org/10.37630/jpm.v10i1.260. 
Slameto. (2010). Belajar dan Faktor_Faktor yang Mempengaruhinya. Jakarta: Rineka Cipta.

Sukawati, S. (2021). Pemanfaatan zoom meeting dan google classroom dalam mata kuliah inovasi. Jurnal Semantik, 10(1), 45-54. https://doi.org/10.22460/semantik.v10i1.p45-54.

Susilo, A., Rumende, C. M., Pitoyo, C. W., Santoso, W. D., Yulianti, M., Herikurniawan, H., ... Yunihastuti, E. (2020). Coronavirus Disease 2019: Tinjauan Literatur Terkini. Jurnal Penyakit Dalam Indonesia, 7(1), 45. https://doi.org/10.7454/jpdi.v7i1.415.

Suyanti, S., Sari, M. K., \& Rulviana, V. (2021). Media Powtoon Untuk Meningkatkan Motivasi Belajar Siswa Sekolah Dasar. Elementary School: Jurnal Pendidikan Dan Pembelajaran Ke-SD-An, 8(2), 322-328. https://doi.org/10.31316/esjurnal.v8i2.1468.

Yuliany, N. (2018). Hubungan Antara Motivasi Belajar Dan Hasil Belajar Siswa Sdn Emmy Saelan Makassar. Jurnal Pendidikan Dasar Islam, 5(2). https://doi.org/DOI: https://doi.org/10.24252/auladuna.v5i2a1.2018.

Zhu, N., Zhang, D., Wang, W., Li, X. Yang, B., Song, J., \& Tan, W. (2020). A Novel Coronavirus from Patients with Pneumonia in China, 2019. The New England Journal of Medicine, 382(8), 727-733. https://doi.org/10.1056/NEJMoa2 001017. 